\title{
Beta-glucan prevents toxic effects of 2,3,7,8-TCDD in terms of oxidative and histopathological damage in heart tissue of rats
}

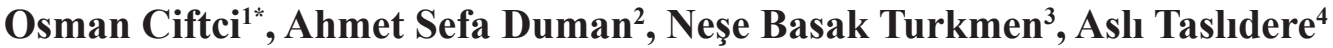

\begin{abstract}
${ }^{1}$ Department of Pharmacology, Faculty of Medicine, Pamukkale University, Denizli, Turkey, ${ }^{2}$ Faculty of Medicine, Inönü University, Malatya, Turkey, ${ }^{3}$ Department of Pharmaceutical Toxicology, Faculty of Pharmacy, Inönü University, Malatya, Turkey, ${ }^{4}$ Department of Histology and Embryology, Faculty of Medicine, Inönü University, Malatya, Turkey
\end{abstract}

\begin{abstract}
2,3,7,8-Tetrachlorodibenzo- $p$-dioxin (TCDD) is a widespread environmental contaminant which causes severe toxic effects. Despite there is some suggestion concerning with TCDD induced cardiotoxicity such as formation of free radicals, the main mechanism has not been entirely explained. Beta-glucan is known as strong antioxidant matter and can scavenge free radicals. Therefore this study aimed to investigate the protective effects of beta-glucan against TCDD induced cardiotoxicity in rats. In this study, 2-3 months of age and 190-250 g in weight 32 rats were randomly divided into four equal groups ( $\mathrm{n}=8$ for each group). Group 1 was control; Group 2 was TCDD group $(2 \mu \mathrm{g} / \mathrm{kg} /$ week); group 3 was the beta-glucan group $(50 \mathrm{mg} / \mathrm{kg} /$ day $)$, and group 4 was TCDD and beta-glucan treatment group. The heart samples were taken from rats after 21 days treatment. The results were shown that Despite TCDD exposure visibly caused to increase $(\mathrm{p} \leq 0.001)$ in TBARS levels, It caused a visible decline in the levels of GSH, CAT, GSH-Px, and SOD. However Beta glucan significantly increased GSH, CAT, GSH-Px, SOD levels and decreased generation of TBARS. Additionally, our histopathological observations were in agreement with the biochemical results. In conclusion, Beta-glucan treatment exhibited protective activity on TCDD induced cardiotoxicity.
\end{abstract}

Keywords: Beta-glucan/protective effects. 2,3,7,8-Tetrachlorodibenzo-p-dioxin (TCDD). Cardiotoxicity. Rats.

\section{INTRODUCTION}

The well known organic toxicant $\operatorname{TCDD}(2,3,7,8$ Tetrachlorodibenzo- $p$-dioxin) is the primary member of polychlorinated dibenzo $p$-dioxins (PCDD).This dioxin is most common environmental contaminant which is generated as by-product of numerous of industrial processes such as incineration(waste materials and metals), chlorine bleaching of paper, chemicals(herbicide production to plants) and metal refining (Hassoun, Vodhanel, Abushaban, 2004; Çiftçi, 2010). TCDD has a prolonged half-life ( 7,6 years in human body) owing to its high stable and lipophilic nature. Therefore these chemicals are prevalent in environment and food chain as a toxic agent and accumulate in liver adipose tissue causing some health problems

\footnotetext{
*Correspondence: Osman Ciftc1. Faculty of Medicine, Pamukkale University, Department of Medical Pharmacology, 44280 Malatya. Phone: +905325646122. E-mail: osmciftci@gmail.com
}

(Bonefeld-Jorgensen, 2010; Gasiewicz et al., 1983). Recent studies (Pohjanvirta, Tuomisto, 1994; Türkez, Geyikoglu, Yousef, 2012) demonstrated that TCDD triggered many degenerative processes in rodents such as carcinogenesis, reproductive toxicity, teratogenicity, wasting syndrome, hepatotoxicity, endocrine changes. Also, TCDD induces many damages at the cellular level including lipid peroxidation, cell membrane disruption, DNA and protein damage, by accelerating ROS generation. The molecular mechanism of TCDD comprises binding and activation of an intracellular ligand-dependent transcription factor, the aryl hydrocarbon receptor(AhR). Ah receptor is an omnipresent protein in the rodent and human cells, which transduces signal and activate gene transcription (Hassoun, Vodhane1, Abushaban, 2004; Ray, Swanson, 2009). Moreover, it has been identified that TCDD perniciousness is related with their oxidative effects in some tissue such as heart, liver and brain (Hassoun et al., 2006; Çiftçi et al., 2012; Çiftçi, Vard1, Ozdemır, 2013). It was suggested that 
using antioxidative chemical compounds might counteract the toxicity of TCDD.Previous studies (Çiftçi, Dişli, Timurkaan, 2013; Kopf, Huwe, Walker, 2008)indicated that TCDD had been related to cardiotoxicity and cardiovascular dysfunctions. However, the exact mechanism of TCDDinduced cardiotoxicity has not been well elucidated yet.

Beta-glucan is a member of polysaccharides that are present in the cell wall of fungi, barley fiber, yeast, medicinal mushroom and actinomycetes (Hendler, Rorvik, 1995). Beta-glucan has advantageous consequences on the immune system and lack of harmful or side effect. Thus beta-glucan has fascinated many researches to investigate its beneficial properties (Carrow, 1996). To date, studies showed that beta-glucans increase hematopoietic activity and wound healing (Wei, Williams, Browder, 2002; Delatte et al., 2001). It protects against viral, fungal, bacterial and parasitic infections in human and rodents as well as stimulate antitumoral activity (Kernodle, Gates, Kaiser, 1998; Onderdonk et al., 1992). Moreover, they decrease the blood lipids such as cholesterol and triglycerides (Keenan et al., 2007; Talati et al., 2009). Beta glucan has some protective effects that are related to the antioxidative property of molecule (Krizkova et al., 2003; Babincova et al., 2002).

The current study aims to investigate the possible protective effects of beta-glucan against TCDD-induced oxidative heart damage by measuring biochemical parameters (oxidant/antioxidant parameters) and histopathological changes.

\section{MATERIAL AND METHODS}

\section{Chemicals}

Beta-glucan were purchased from Sigma (CAS no: 9012-72-0) 2,3,7,8-TCDD(purity $>99 \%$ ) was obtained from Accustandart, Inc. (New Haven, Connecticut, USA).

\section{Animals and treatment}

32 healthy adult female Sprague-Dawley rats (2 -3 months of age and 190-250 g in weight) were obtained from Experimental Animal Institute, Malatya, Turkey. Animals were placed in sterilized polypropylene rat cages, in 12-h light-dark cycle, at an ambient temperature of 21 ${ }^{\circ} \mathrm{C}$. Standart commercial pellets and drinking water were given ad libitum. Experiments were performed on the basis of animal ethics guidelines of Institutional Animals Ethics Committee. Rats were randomly divided into four equal groups ( $\mathrm{n}=8$ in each group). Group 1 (control) served as negative control and was given distilled water by gavages.
In group 2 (TCDD group), TCDD was orally administered at the doses of $2 \mu \mathrm{g} / \mathrm{kg} / \mathrm{week}$. Rats in group 3 were treated with beta-glucan suspended in CMC at the doses of $50 \mathrm{mg} / \mathrm{kg} / \mathrm{day}$. In group 4, rats were treated with TCDD and beta-glucan (TCDD+beta-glucan group) at the same time. Tissue samples from rats were collected 21 days after the treatment. The animals were killed under slight ether anesthesia, and heart tissues were immediately removed and dissected over ice-cold glass. Tissue samples were stored at $-80^{\circ} \mathrm{C}$ in a deep freeze until analysis.

\section{Biochemical assay}

The homogenization of tissues was prepared with Teflon glass homogenizer in $150 \mathrm{mM}$ phosphate buffer $(\mathrm{pH} 7,4)$ to obtain 1:10 (w/v) dilution of the whole homogenate, adjusting to cold chain. Lipid peroxidation was determined by measuring Thiobarbituric acid reaction using the method of Yagi (1998). TBARS level is an indicator of lipid peroxidation. The product was evaluated spectrophotometrically at $532 \mathrm{~nm}$, and results are shown as nmol/g tissue. The reduced glutathione (GSH) content of the heart homogenate was measured at $412 \mathrm{~nm}$ and confirmed as nmol/mL using the method of Sedlak and Lindsay (1968). Determination of SOD enzyme activity was based on generation of hydrogen peroxide $\left(\mathrm{H}_{2} \mathrm{O}_{2}\right)$, from xanthine by xanthine oxidase and inhibition of nitrobluetetrazolium (NBT) as previously described by Sun, Oberley and Li (1988). The product was evaluated spectrophotometrically at $560 \mathrm{~nm}$, and the results were expressed as units per milligram protein. Catalase (CAT) activity in heart tissue was determined by using the method of Aebi (1974). The essential principle of this technique is based on the determination of the rate constant ( $/ \mathrm{k}$ ) or the $\mathrm{H}_{2} \mathrm{O}_{2}$ decomposition rate at $240 \mathrm{~nm}$. Results were expressed as k per gram protein ( $\mathrm{k} / \mathrm{g}$ protein). Glutathione peroxidase (GPx) activity was measured by the method of Paglia and Valentina (1967). An enzymatic reaction in a tube containing NADPH, GSH, sodium azide and glutathione reductase was initiated by the addition of $\mathrm{H}_{2} \mathrm{O}_{2}$, and the decrease in absorbance at $340 \mathrm{~nm}$ was monitored by a spectrophotometer. The results were expressed in units per gram protein ( $\mathrm{U} / \mathrm{mg}$ protein). The protein content of tissue was determined according to the method of Lowry et al. (1951) by using bovine serum albümin as standard.

\section{Histological analysis}

For light microscopic evaluation, heart samples were fixed in $10 \%$ formalin. The heart samples were processed by routine tissue techniques and were embedded 
in paraffin. Paraffin-embedded specimens were cut into 5 mm thick sections, mounted on slides and stained with Hematoxylin-Eosin (H-E). Sections examined under a Leica DFC280 light microscope by Leica Q Win and Image Analysis System (Leica Micros Imaging Solutions Ltd.; Cambridge, U.K).

We examined sections for eosinophilic stained and pyknotic nuclei cells, necrosis, hemorrhage, mononuclear cell infiltration, edema, vascular congestion, and vacuolization. Histopathologic damage score has calculated these findings. Statistical analysis was made with SPSS 13.0 (SPSS Inc., Chicago, Ill., USA) and MedCalc 11.0 (Belgium) statistical programs. All data are expressed as arithmetic mean $\pm \mathrm{SE}$. For comparisons between groups, Kruskal-Wallis and Connover tests were used. Exact $\mathrm{p}$ values were given where available, and $\mathrm{p}<$ 0.0001 was accepted as statistically significant.

\section{Statistical analysis}

Acomputer program SPSS 11.0(SPSS Inc., Chicago, Illinois, USA) was used for statistical analysis. The statistical analyses were performed using one-way analysis of variance and post hoc Tukey's honestly significant difference test. All values were presented as mean \pm SEM

\section{RESULTS}

\section{Biochemical Results}

The levels of SOD, GSH-Px, CAT, GSH and TBARS in heart are presented in Table I. The results showed that TBARS levels were significantly $(\mathrm{p} \leq 0.001)$ increased, but TCDD caused a significant $(\mathrm{p} \leq 0.001)$ decrease in the levels of SOD, GSH-Px, CAT, and GSH in that exposure to TCDD compared to with control and other groups. It was shown that TCDD apparently increased the lipid peroxidation in heart tissue. In general, beta-glucan treatment did not significantly change the antioxidant enzymes activities, GSH and TBARS levels compared to control group. Beta-glucan when given together with TCDD changed the levels of SOD, GSHPx, CAT, GSH and TBARS closer to the control level. Finally, the results showed that beta-glucan significantly reduced lipid peroxidation in heart tissue.

\section{Histological results}

In control (Figure 1A) and beta-glucan (Figure 1B) groups, heart tissue showed normal histological appearance. In TCDD group, we detected eosinophilic stained and pyknotic nuclei cells, necrosis (Figure 2A,B), hemorrhage (Figure 2A,B,C,D) mononuclear cell infiltration (Figure 2D), oedema (Figure 2C), vascular congestion (Figure 2E) and vacuolisation (Figure 2C). Beta-glucan supplementation significantly reduced TCDD-induced histopathological changes (Figure 3A, B, C). Heart damage was decreased in this group.

\section{DISCUSSION}

Up to now, it has been reported that TCDD exposure caused histological damage in many organs including the heart in laboratory animals. In the present study, it was demonstrated that the exposure of TCDD could decrease antioxidant enzymes and increase lipid peroxidation in heart tissue. On the other hand, antioxidant materials such as beta-glucan exhibit a protective effect against cardiotoxicity of TCDD. The findings showed that 50 $\mathrm{mg} / \mathrm{kg} /$ day beta-glucan treatment prevented oxidative
CONTROL

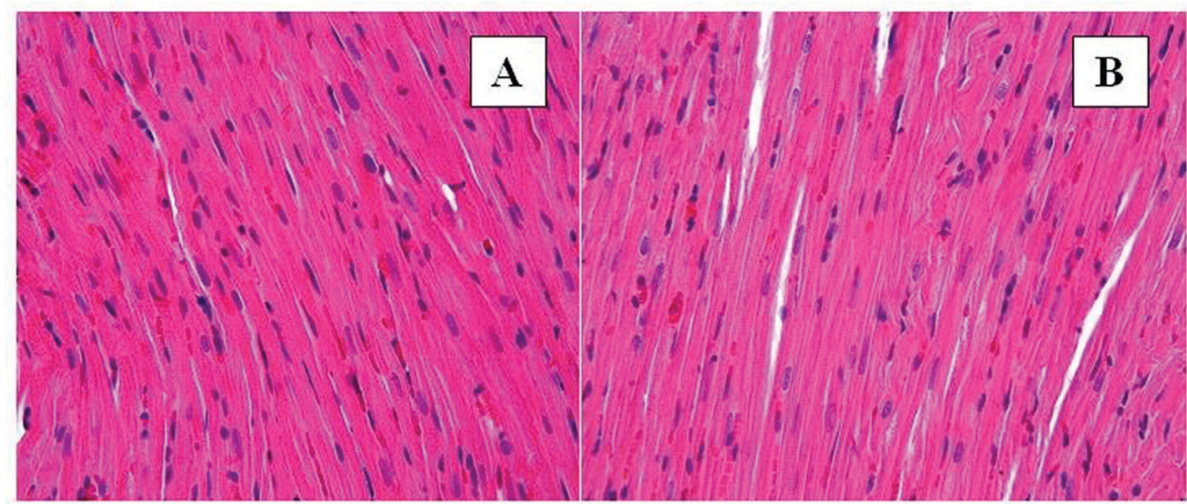

FIGURE 1 - Control and Beta glucan group. In control and beta-glucan groups heart tissue showing the normal appearance of cardiac myofibres. (A): H-E; X40, (B): H-E; X40. 


\section{TCDD GROUP}
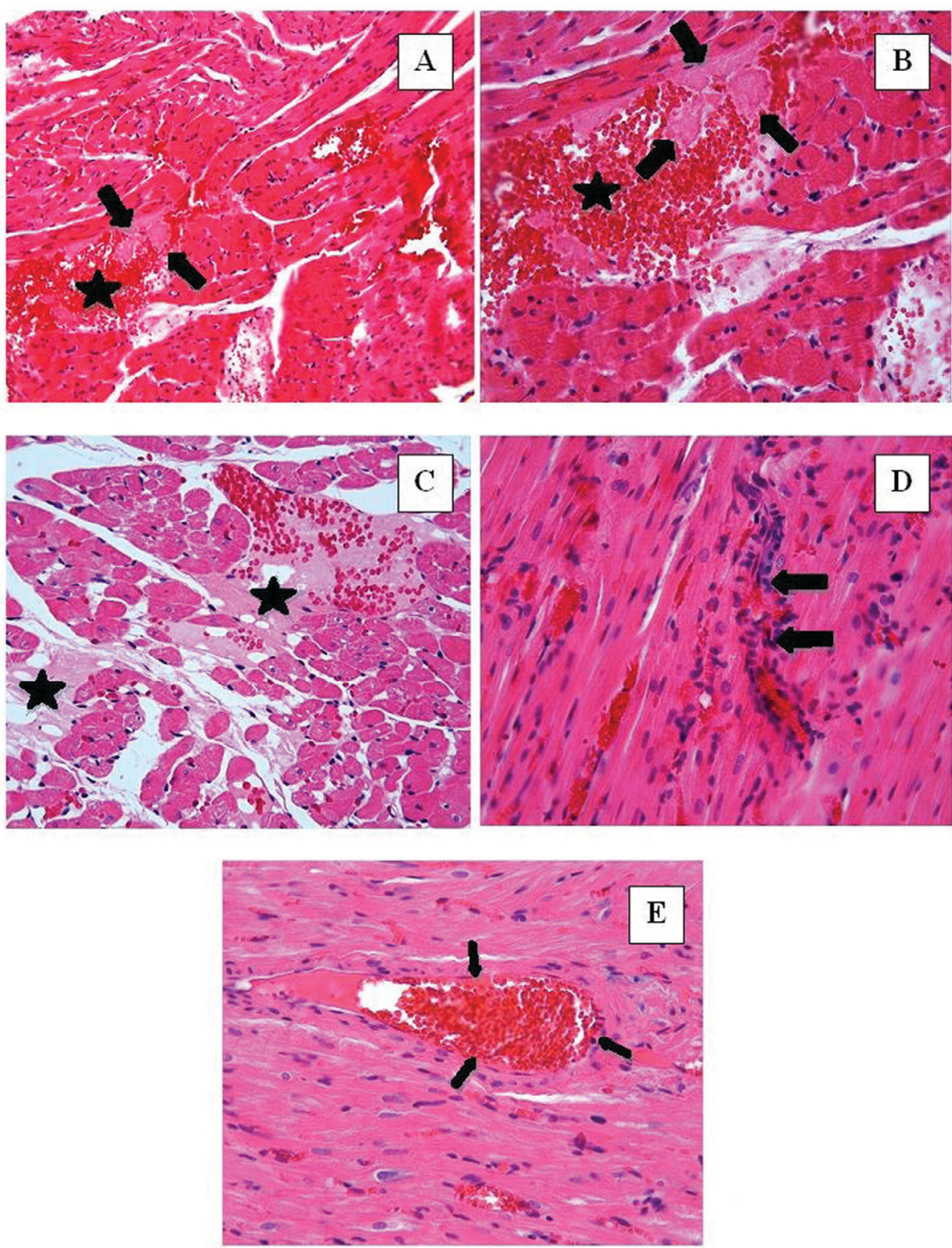

FIGURE 2 - TCDD group. Eosinophilic stained and pyknotic nuclei cells, necrosis (A,B), hemorrhage (A,B,C,D), mononuclear cell infiltration (D), oedema (arrows) (C), vascular congestion (E) and vacuolisation (C). A, B: H-E; X20, C, D, E: H-E; X40.

and histopathological damage of TCDD in heart tissue of female rats.

TCDD causes oxidative stress by generating an unbalance between the free radicals and antioxidant status. TCDD induced oxidative stress has a significant role in the etiology of some diseases including cardiovascular diseases (Çiftçi, Vard1, Ozdemir, 2013). It is determined that TCDD correlated with oxidative stress as a result of elevation of TBARS levels (Montjean et al., 2010). In the current study, it was showed that TCDD exposure caused elevation of TBARS levels and decreased SOD,
GSH and CAT levels in the heart tissue in comparison to control group rats. TBARS were formed as a byproduct of lipid peroxidation due to TCDD exposure. Elevated levels of TBARS is thought a sign of cell damage and lipid peroxidation. However, it is not known how the exact mechanism of TCDD affects heart tissue.There are some studies (Çiftçi et al., 2012; Çiftçi, Vard1, Ozdemir, 2013) showing the oxidative effects of TCDD on other tissues such as liver and testis. Similar to our study, previous studies stated that TCDD led to lipid peroxidation in many organs.Likewise, after low dose of TCDD exposure, 
TCDD + BETA-GLUCAN
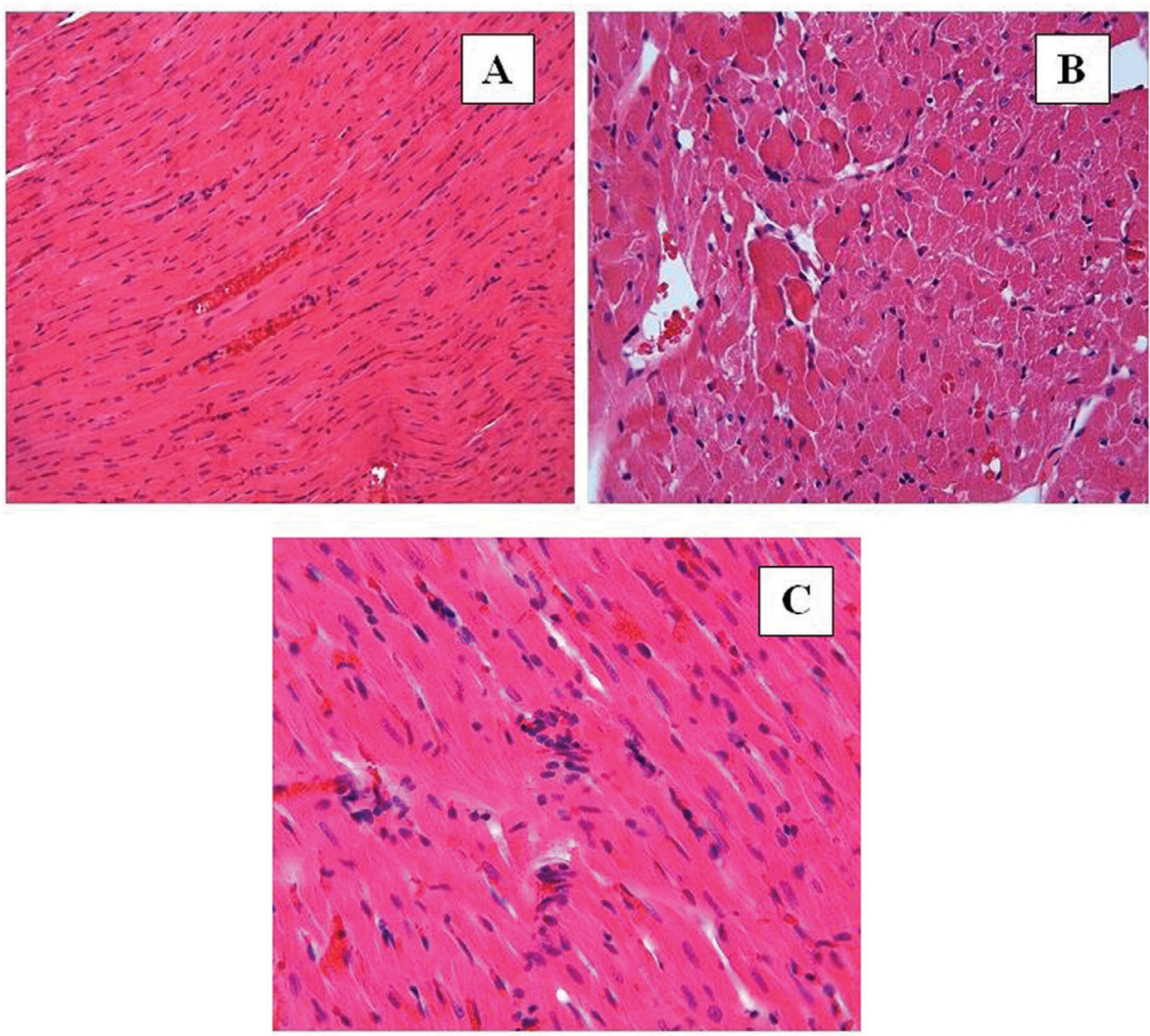

FIGURE 3 - TCDD + beta-glucan group. Degenerative changes were decreased in TCDD+beta-glucan group compared with TCDD group. A: H-E; X20, B, C: H-E; X40.

it was observed that antioxidant defense system(both enzymatic and nonenzymatic) were reduced. Antioxidant compounds(SOD, CAT, GPx, and GSH) protects cells against free radical damage (Schiller, Reilly, Bulkley, 1993). Similiar studies (Hassoun et al., 2006) reported that TCDD disrupted function of the antioxidant defense system in some tissues. This results are in accordance with previous results and verify our findings. Ultimately, it is obvious that TCDD exposure may cause oxidative damage and histological damage in rat heart tissue. On the other hand, our study showed that beta-glucan treatment could prevent oxidative damage of TCDD on rat heart tissue with decreasing high TBARS levels and causing an increase in GSH, CAT levels. As far as we know, there was no study about protectivity of beta-glucan in heart tissue against oxidative damage. On the other hand, some studies determined that beta-glucan exhibits potent antioxidant activity and has apparent protective effect on cell damage (Krizkova et al., 2003; Babincova et al., 2002). In this study, beta-glucan was undertaken to evaluate it's antioxidant and protective activity on structure and histoarchitecture of the heart tissue. Oxidative stress is regarded as an important risk factor for many diseases and aging. According to these results, we could announce that antioxidant properties of beta-glucan can protect against TCDD's toxicity in rat heart tissue by acting as a scavenger of oxygen radical.

In the histopathological evaluation, it was observed that TCDD exposure led to obvious histopathological changes such as necrosis and hemorrhage in cardiac tissue in comparison to the control groups.Similar to our study (Kopf, Hüwe, Walker, 2008) reported that TCDD causes severe damage to the heart and other tissues including kidney, liver, and testis. These results are in accordance with our findings and confirm our results. According to our results, beta-glucan treatment significantly enhanced antioxidant activities and cell viabilities. Besides it partially reversed the histopathological toxic effects of TCDD on heart tissue. As far as we are aware it is not fully explained the protective mechanism of beta-glucan on TCDD-induced cardiotoxicity. Our study is the first to determine that beta-glucan could be useful in TCDD induced cardiotoxicity as a preventive agent. It was thought that the histopathological effects might attribute 
to an imbalance between oxidant and antioxidant status in heart tissue induced by TCDD. Therefore, beta-glucan treatment has dominative protective role for preventing histopathological damage in heart tissue and reduction of oxidative stress.

\section{CONCLUSION}

The present study shows that TCDD exposure at the dose of $2 \mu \mathrm{g} / \mathrm{kg} /$ week leads to oxidative and histopathological damages in heart tissue of rats. Moreover, beta-glucan (50 mg/kg/day) had strong antioxidative potentials and partially prevented toxic effects of TCDD on histopathological changes. The protective effect of beta-glucan against TCDD induced toxicity suggests that beta-glucan treatment is a promising source for the development of potential protectors against TCDD-induced cardiotoxicity and oxidative stress. Thus, We thought that beta-glucan might be useful for the prevention and treatment of TCDD induced cardiotoxicity.

\section{REFERENCES}

Aebi H. Catalase. In: Bergmeyer HU (ed.) In: Methods of enzymatic analysis. New York: Academic Press; 1974;673-677.

Babincová M, Bacová Z, Machová E, Kogan G. Antioxidant properties of carboxymethyl glucan: comparative analysis. J Med Food. 2002;5(2):79-83.

Bonefeld-Jorgensen EC. Biomonitoring in Greenland: human biomarkers of exposure and effects - a short review. Rural Remote Health. 2010;10(2):1362. PMID:20572746.

Carrow DJ. Beta-1,3-glucan as a primary immune activator. Townsend Lett. 1996;86-91.

Ciftci O, Aydin M, Ozdemir I, Vardi N.Quercetin prevents 2,3,7,8-tetrachlorodibenzo-p-dioxin-induced testicular damage in rats. Andrologia. 2012;44(3):164-73.

Ciftci O, Disli OM, Timurkaan N. Protective effects of protocatechuic acid on TCDD-induced oxidative and histopathological damage in the heart tissue of rats. Toxicol Ind Health. 2013;29(9):806-11.

Ciftci O, Vardi N, Ozdemir I. Effects of quercetin and chrysin on 2,3,7,8-tetrachlorodibenzo-p-dioxin induced hepatotoxicity in rats. Environ Toxicol. 2013;28(3):146-54
Ciftci O. The Investigation of effect mechanism,chemical structure and toxicokinetics properties of dioxins compounds. J TOMC. 2010;17:413-422.

Delatte SJ, Evans J, Hebra A, Adamson W, Othersen HB, Tagge EP.Effectiveness of beta-glucan collagen for treatment of partialthickness burns in children. J Pediatr Surg. 2001;36(1):113-8.

Gasiewicz TA, Geiger LE, Rucci G, Neal RA. Distribution, excretion, and metabolism of 2,3,7,8-tetrachlorodibenzo-pdioxin in C57BL/6J, DBA/2J, and B6D2F1/J mice. Drug Metab Dispos. 1983;11(5):397-403.

Hassoun EA, Vodhanel J, Abushaban A. Themodulatory effects of ellagic acid and vitamin E succinate on TCDD-induced oxidative stress in different brain regions of rats after subchronic exposure. J Biochemic M Toxicol. 2004;18(4):196-203.

Hassoun EA, Vodhanel J, Holden B, Abushaban A. The effects of ellagic acid and vitamin $\mathrm{E}$ succinate on antioxidant enzymes activities and glutathione levels in different brain regions of rats after subchronic exposure to TCDD. J Toxicol Env. 2006;69(5):381-393.

Hendler SS, Rorvik D. PDR for Nutritional Supplements. 1st ed. Ontario: Thomas Healthcare; 1995.

Keenan JM, Goulson M, Shamliyan T, Knutson N, Kolberg L, Curry L.The effects of concentrated barley beta-glucan on blood lipids in a population of hypercholesterolaemic men and women. Br J Nutr. 2007;97(6):1162-8.

Kernodle DS, Gates H, Kaiser AB. Prophylactic antiinfective activity of poly-[1-6]-beta-D-glucopyranosyl-[13]-beta-D-glucopryanose glucan in a guinea pig model of staphylococcal wound infection. Antimicrob Agents Chemother. 1998;42(3):545-9.

Kopf PG, Huwe JK, Walker MK. Hypertension, cardiac hypertrophy, and impaired vascular relaxation induced by 2,3,7,8-tetrachlorodibenzo-p-dioxin are associated with increased superoxide.Cardiovasc Toxicol. 2008;8(4):181-93.

Krizková L, Duracková Z, Sandula J, Slamenová D, Sasinková V, Sivonová M, Krajcovic J. Fungal beta-(1-3)-D-glucan derivatives exhibit high antioxidative and antimutagenic activity in vitro. Anticancer Res. 2003;23(3B):2751-6.

Lowry OH, Rosebrough NJ, Farr AL, Randall RI. Protein measurement with folin phenol reagent. J Biol Chem. 1951;193(1):265-275. 
Montjean D, Ménézo Y, Benkhalifa M, Cohen M, Belloc S, Cohen-Bacrie P, de Mouzon J. Malonaldehyde formation and DNA fragmentation: two independent sperm decays linked to reactive oxygen species.Zygote. 2010;18(3):265-8.

Onderdonk AB, Cisneros RL, Hinkson P, Ostroff G. Anti-infective effect of poly-beta 1-6-glucotriosyl-beta 1-3-glucopyranose glucan in vivo.Infect Immun. 1992;60(4):1642-7.

Paglia DE, Valantine WN. Studies on the quantitative and qualitative characterization of erythrocyte glutathione peroxidase. J Laband Clinic Med. 1967;70(1):158-169.

Pohjanvirta R, Tuomisto J. Short-term toxicity of 2,3,7,8-tetrachlorodibenzo-p-dioxin in laboratory animals: effects, mechanisms, and animal models. Pharmacol Rev. 1994;46(4):483-549.

Ray S, Swanson HI. Activation of the aryl hydrocarbon receptor by TCDD inhibits senescence: a tumor promoting event. Biochem Pharmacol. 2009;77(4):681-8.

Schiller HJ, Reilly PM, Bulkley GB. Tissue perfusion in critical illnesses. Antioxidant therapy. Crit Care Med. 1993;21(2 suppl):92-102.
Sedlak J, Lindsay RH. Estimation of total, protein-bound, and nonprotein sulfhydryl groups in tissue with Ellman's reagent. Anal Biol. 1968;25:192-205.

Sun Y, Oberley LW, Li YA. Simple method for clinical assay of superoxide dismutase. Clin Chem. 1988;34(3):497-500.

Talati R, Baker WL, Pabilonia MS, White CM, Coleman CI. The effects of barley-derived soluble fiber on serum lipids. Ann Fam Med. 2009;7(2):157-63.

Türkez H, Geyikoglu F, Yousef MI. Ameliorative effect of docosahexaenoic acid on 2,3,7,8-tetrachlorodibenzo-p-dioxininduced histological changes, oxidative stress, and DNA damage in rat liver.Toxicol Ind Health. 2012;28(8):687-96.

Wei D, Williams D, Browder W. Activation of AP-1 and SP1 correlates with wound growth factor gene expression in glucan-treated human fibroblasts. Int Immunopharmacol. 2002;2(8):1163-72.

Yagi K. Simple assay for the level of total lipid peroxides in serum or plasma. M Molecul Bio. 1998;108:101-106.

Received for publication on $17^{\text {th }}$ October 2017 Accepted for publication on $14^{\text {th }}$ December 2017 